\title{
Clinical Relevance of Disseminated Tumor Cells in the Bone Marrow and Circulating Tumor Cells in the Blood of Breast Cancer Patients
}

\author{
Volkmar Müller ${ }^{a^{*}} \quad$ Tanja Fehm $^{\mathrm{b}^{*}} \quad$ Wolfgang Janni $^{\mathrm{c}^{*}} \quad$ Gerhard Gebauer $^{\mathrm{d}^{*}} \quad$ Erich Solomayer $^{\mathrm{b}^{*}}$ \\ Klaus Pantel $\mathrm{e}^{*}$ \\ a Department of Gynecology, University Medical Center Hamburg-Eppendorf, \\ ${ }^{\mathrm{b}}$ Department of Obstetrics and Gynecology, University of Tübingen, \\ ${ }^{c}$ Department of Obstetrics and Gynecology, Heinrich Heine University, Düsseldorf, \\ ${ }^{\mathrm{d}}$ Department of Obstetrics and Gynecology, University of Heidelberg, \\ ${ }^{\mathrm{e}}$ Institute of Tumor Biology, University Medical Center Hamburg-Eppendorf, Germany
}

\section{Key Words}

Breast cancer - Bone marrow - Blood .

Disseminated tumor cells · Circulating tumor cells

\section{Summary}

Subclinical tumor cell spread, as the putative precursor stage of subsequent solid metastases, can be assessed in breast patients via the detection of disseminated tumor cells (DTC) in bone marrow aspirates or circulating tumor cells (CTC) in the peripheral blood with immunocytochemical and molecular techniques. In the context of a growing number of treatment strategies for cancer patients in the adjuvant setting as well as in the metastatic situation, markers predicting therapy efficacy are urgently needed. The detection of DTC or CTC may become one of the most interesting parameters not just for the prediction of survival or therapy monitoring but also for the characterization and specific targeting of residual tumor cells. Progress in this field now permits clinical studies that should lead to improvements in the treatment of breast cancer patients.

\section{Schlüsselwörter}

Mammakarzinom · Knochenmark ·

Disseminierte Tumorzellen · Zirkulierende Tumorzellen

\section{Zusammenfassung}

Die subklinische Streuung von Tumorzellen als das Vorläuferstadium solider Metastasen kann bei Brustkrebspatienten durch die Detektion disseminierter Tumorzellen (DTC) in Knochenmarkaspiraten oder zirkulierender Tumorzellen (CTC) im periphären Blut mittels immunzytochemischer und molekularer Methoden beurteilt werden. Im Rahmen der stetig wachsenden Anzahl an Behandlungsstrategien für Krebspatienten sowohl im adjuvanten Setting als auch im metastasierten Stadium werden Marker zur Vorhersage der Behandlungseffizienz dringend benötigt. Die Detektion von DTC bzw. CTC könnte zu einem der interessantesten Parameter werden, sowohl für die Vorhersage des Überlebens und zum Zweck des Therapiemonitoring als auch für die Charakterisierung und das spezifische Targeting residueller Tumorzellen. Fortschritte auf diesem Gebiet lassen nunmehr klinische Studien zu, die zu Verbesserungen in der Behandlung von Brustkrebspatienten führen dürften.

\footnotetext{
* All authors have contributed equally to this manuscript
}

\begin{tabular}{ll}
\hline KARGER & $\oplus$ 2009 S. Karger GmbH, Freiburg \\
Fax +497614520714 & Accessible online at: \\
Information@Karger.de & www.karger.com/brc \\
www.karger.com &
\end{tabular}




\section{Relevance of Disseminated Tumor Cells in the Bone Marrow}

The predominant cancer-associated cause of death in patients with solid tumors is commonly not the primary tumor but distant metastases which can develop even years after the treatment of the primary tumor. A relevant portion of breast cancer patients with negative axillary lymph nodes, for example, develop local or distant metastases during the further course of the disease, even if there was no indication of dissemination beyond the breast at the time of the first diagnosis [1]. Metastases are probably caused by the occult dissemination of tumor cells into the blood in the early stages of the disease. Several studies support the hypothesis that disseminated tumor cells (DTC; also called minimal residual disease, MRD) in the bone marrow (BM), can be considered to be the precursor of clinically manifested distant metastases [2-5].

The question whether BM involvement presents an independent prognostic marker was resolved and summed up recently with data of a pooled analysis [6]. Within the scope of this analysis, data on the survival rate of 4,703 stage I-III breast cancer patients from 9 different centers were evaluated with regard to $\mathrm{BM}$ status. The overall positivity rate in $\mathrm{BM}$ was $31 \%$. The positive BM status represented an independent prognostic marker for overall survival as well as for diseasespecific survival.

Evidence of persistent tumor cells after the completion of chemotherapy or during the follow-up period could be of higher clinically importance, especially with regard to newer targeted therapies. A joint analysis of data from 726 patients confirmed earlier single-center results: the overall survival among $15.4 \%$ of those patients examined with evidence of persistent tumor cells in BM differed by 62 months $(\mathrm{p}<0.0001)$ [7]. Evidence of persistent isolated tumor cells in BM as part of breast cancer surveillance may serve as surrogate marker for the need of further adjuvant therapy in the future.

\section{Relevance of Circulating Tumor Cells in the Blood}

Sequential peripheral blood analyses should be more acceptable than BM aspirations, and many research groups are currently assessing circulating tumor cells (CTC) in clinical studies. Depending on the detection technique used, CTC were revealed in $50-100 \%$ of patients with metastatic breast cancer [8]. Even in patients with no clinical signs of overt metastases, detection rates range from 10 to $60 \%$ [9]. However, it was also described that detection of DTC in BM had superior prognostic significance in comparison with CTC measurements in blood, analyzing patients with metastatic and non-metastatic breast cancer by a quantitative reverse transcription-polymerase chain reaction (RT-PCR) assay for cytokeratin-19 and mammaglobin mRNAs [10]. One possible explanation is that $\mathrm{BM}$ is a homing organ for DTC, whereas blood analyses allow only a 'snap shot' of tumor cell dissemination. Taken together, these findings do not support an exchange of DTC in BM with CTC from blood, but future studies with improved detection technologies may help to clarify this issue. Several studies also have used RT-PCR-based methods to detect CTC and showed a prognostic impact [11-13].

As described above, the clinical relevance of CTC measurements is still under investigation. In the metastatic setting, detection of CTC with the CellSearch ${ }^{\mathrm{TM}}$ system (Veridex, Raritan, NJ, USA) provided significant prognostic information before and also shortly (4 weeks) after initiation of chemotherapy in patients with measurable metastatic breast cancer $[14,15]$. Interestingly, CTC determinations seem to be superior to conventional imaging methods for response evaluation [16]. The clinical utility of these findings is now being prospectively addressed in a randomized trial (SWOG S0500) led by the Southwest Oncology Group (www.cancer.gov/clinicaltrials/SWOG-S0500). The aim of this trial is to determine whether women with metastatic breast cancer and CTC levels of 5 or more cells per $7.5 \mathrm{ml}$ of blood after 3 weeks of first-line chemotherapy show an improved overall survival and progression-free survival when changing to an alternative chemotherapy regimen in the next course rather than waiting for clinical evidence of progressive disease.

In contrast to patients with metastatic disease, less information is available about the prognostic relevance of CTC in the blood of patients with early-stage disease [17]. To monitor treatment efficacy is of great clinical relevance especially in the adjuvant setting when no measurable tumor is present. In patients with primary breast cancer, several studies are currently evaluating the detection of CTC. In the German neoadjuvant trial 'GeparQuattro' (www.germanbreastgroup.de/ geparquattro), CTC determinations were performed with the CellSearch system before and after primary systemic chemotherapy. The positivity rate defined as the detection of 1 or more CTC was $22 \%$ before treatment and decreased to $14 \%$ after chemotherapy [18]. As part of the translational research project of the German SUCCESS trial, peripheral blood from 1,500 node-positive and high-risk node-negative breast cancer patients before and after adjuvant taxane-based chemotherapy was examined for the presence of CTC with the CellSearch system. In $10 \%$ of the patients, more than 1 CTC was detected before the start of systemic treatment. After completion of chemotherapy, $9 \%$ of patients presented with $>1$ CTC. While the presence of CTC before systemic treatment did not show prognostic relevance, persistence of CTC after chemotherapy was a significant predictor for reduced disease-free and overall survival [19].

\section{Molecular Characterization of Disseminated Tumor Cells}

The purpose of characterizing DTC is to improve the understanding of the metastatic process and also to reveal diagnos- 
tically and therapeutically relevant features. However, the molecular and phenotypic characterization of DTC remains a challenge mainly because of the few cells available for analysis and the difficulties to isolate them without contamination by other cell types.

At the genomic level, Fehm et al. [20] have shown, using multiple FISH analyses, that the majority of CTC isolated from the blood of breast cancer patients are aneusomic, i.e. have deviations from the normal state of disomy, and are derived from the primary tumor. Comparative genomic hybridization (CGH) has shown that even in early stage breast cancer, DTC in BM are genetically heterogeneous. Interestingly, the early DTC lacked some genomic aberrations found in different regions of the primary tumors [21]. This suggests that DTC evolve independently from the primary tumor and accumulate new genomic aberrations in the course of homing to $\mathrm{BM}$ and other distant organs.

Microarray-based gene expression analyses of primary breast tumors from patients with DTC in BM [22] support the hypothesis that tumor cells acquire the genetic changes relevant to their metastatic capacity early in tumorigenesis [23]. Accordingly, the metastatic potential of DTC already may be encoded in most primary tumor cells [23]. The identification of DTC-specific genes is also the focus of the European consortium DISMAL ('Disseminated Malignancies'; $w w w$. dismal-project.eu). Absence of the proliferation marker Ki-67 in DTC indicates that most DTC in BM are non-proliferating and dormant $[24,25]$. This may explain why adjuvant chemotherapy is ineffective.

Recently, it was shown that most DTC in BM were CD44+/ CD24-/low and expressed stem cell features [26]. A proportion of viable DTC enriched from BM of metastatic and primary breast cancer patients present with a breast cancer stem cell-like phenotype, characterized by CK19-positive status and absence of Muc-1 secretion [27]. Whether DTC can selfrenew, as do stem cells, remains yet to be elucidated.

\section{Targeting of DTC and CTC in Breast Cancer Patients}

A striking potential of CTC could be to re-evaluate therapeutic targets on CTC, as 'real time biopsy' during breast cancer treatment, which might enable a more individual and optimized therapy in cancer patients. Based on the hypothesis that persistent tumor cells are the precursor of subsequent metastatic disease, these patients may benefit from extended/ modified adjuvant therapy. Currently, the two most important targets are the HER2 receptor and estrogen receptor (ER). HER2 overexpression and/or amplification status has been linked with aggressive tumor behavior and resistance to cytotoxic and endocrine therapy [28-30]. HER2-positive patients are eligible for treatment with trastuzumab (Herceptin ${ }^{\circledR}$, Roche Pharma AG, Grenzach-Whylen, Germany) and other therapeutic strategies, e.g. the tyrosine kinase inhibitor lap-

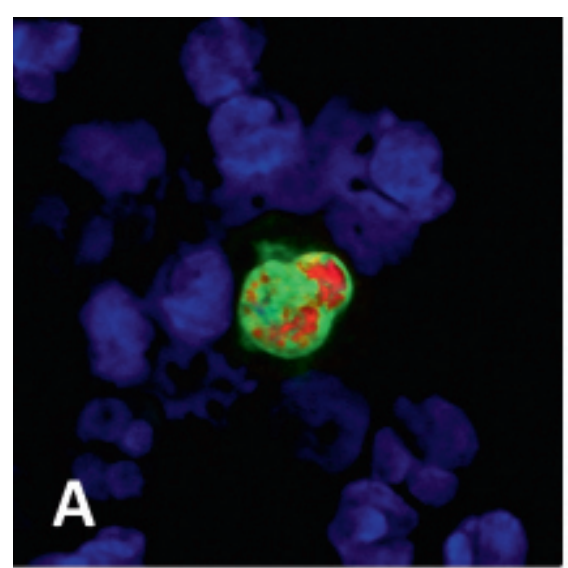

Fig. 1. Phenotyping of disseminated tumor cells (DTC) by double immunofluorescence staining; A ER $\alpha$-positive (red)/CK-positive (green) DTC, B HER2-positive (red)/ CK-positive (green) DTC.

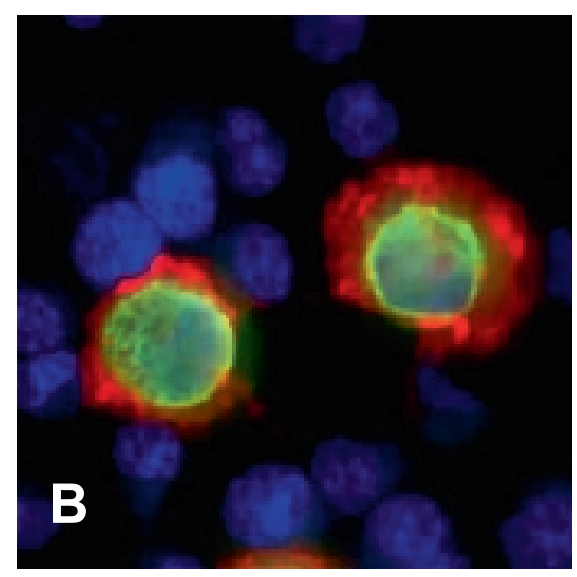

atinib which seems to have clinical activity also after failure of trastuzumab therapy [31]. The phenotype of the primary tumor is the current gold standard for the selection of breast cancer patients for HER2-targeted therapy. However, several studies have indicated that the HER2 status may be different between primary tumor and DTC. An example for HER2 staining of CTC by immunofluorescence is given in figure 1 . The results of several studies investigating the HER2 status of DTC compared to their corresponding primary tumors are summarized in table 1 . Two different hypotheses are discussed for the discrepancy of HER2 status between DTC and primary tumor. One explanation is that tumor cells may acquire HER2 amplification resulting in HER2 overexpression during dissemination and tumor progression, respectively. Another possibility is that a small subclone of HER2-positive cells in the primary tumor, which did not exceed the cut-off for HER2 positivity (10\% of analyzed cells), has shed its tumor cells.

In metastatic patients, it has also been demonstrated that patients with HER2-negative primary tumors have HER2positive CTC in the blood. Moreover, a subset of these patients were treated with trastuzumab and showed clinical response $[32,33]$. Since the number of patients included in these studies was small, no conclusive data have been obtained. In this context, a European multicenter study has been initiated (www.detect-study.de). The aim of this study is to evalu- 
Table 1. Summary of results from several studies investigating the HER2 status of disseminated tumor cells (DTC) compared to their corresponding primary tumors

\begin{tabular}{lccll}
\hline Author [Ref.] & Patients, $n$ & $\begin{array}{l}\text { Primary tumor } \\
\text { HER2-positive, } \\
\%\end{array}$ & $\begin{array}{l}\text { DTC HER2- } \\
\text { positive, } \%\end{array}$ & $\begin{array}{l}\text { Concordance, } \\
\%\end{array}$ \\
\hline Solomayer et al. [42] & 45 & $14(29)$ & $20(44)$ & 63 \\
Becker et al. [43] & 105 & $26(25)$ & $22(21)$ & 77 \\
Braun et al. [44] & 24 & $7(29)$ & $15(63)$ & 58 \\
Meng et al. [32] & 33 & $15(46)$ & $11(33)$ & 88 \\
Vincent-Salomon et al. [45] & 27 & $5(18.5)$ & $4(15)$ & 90 \\
\hline
\end{tabular}

ate the percentage of metastatic breast cancer patients with HER2-positive CTC and HER2-negative primary tumors using different methods for HER2 determination. 250 metastatic breast cancer patients will be enrolled. In addition, the course of HER2-positive CTC under HER2 targeted therapy is evaluated by serial CTC measurements.

\section{ER Status of DTC}

The most widely used form of targeted therapy for breast cancer remains anti-estrogen endocrine therapy, therefore it is important to know whether the ER $\alpha$ status of DTC corresponds to the ER $\alpha$ status of the primary tumor. In our own study, only in 12 of 88 (14\%) patients with ER $\alpha$-positive primary tumors, ER $\alpha$-positive tumor cells could be detected [19]. Similar results are observed by Ditsch et al. [34] who reported that 2 of $11(18 \%)$ patients with ER $\alpha$-positive primary tumors had ER $\alpha$-positive DTC. Reuben et al. [35] investigated the $\mathrm{ER} \alpha$ status of CTC in metastatic breast cancer patients and their corresponding primary tumors: 14 of 16 (88\%) patients had ER $\alpha$-positive primary tumors, but in contrast, only 3 of 16 patients had ER $\alpha$-positive CTC [35]. Therefore, the majority of DTC tend to be ER $\alpha$-negative and will not respond to ER targeted therapy. These results suggest a potential to optimize treatment of breast cancer patients with HER2/ER-negative persistent tumor cells after cytotoxic therapy.

\section{Targeting DTC by Other Treatment Strategies}

\section{Targeting the Microenvironment}

The specific microenvironment determines the extent of cell proliferation, angiogenesis, invasion, and survival of tumor cells and micrometastasis. Bisphosphonates (BP) influence the microenvironment by altered secretion of growth factors and cytokines. Moreover, BP reduce tumor cell adhesion, induce apotosis in tumor cells, have an antiangiogenic effect, and enhance antitumor activity of cytotoxic agents [36]. They are successfully used in conditions of increased bone turnover such as osteoporosis or bone metastases. Small trials have already demonstrated that persistent DTC of primary breast cancer patients can be eliminated by BP probably due to the altered microenvironment $[37,38]$, and the risk of recurrence could be reduced in patients with positive DTC by BP treatment [3].

\section{Targeting Angiogenesis}

Angiogenesis is a critical feature of tumor growth. Therefore, inhibition of angiogenesis is an appealing strategy for treatment. The most promising approach has been the use of bevacizumab, a monoclonal antibody against vascular endothelial growth factor (VEGF) [39]. In the context of eliminating single dormant tumor cells, an anti-angiogenic therapy might be sufficient to maintain the non-proliferative state of the DTC by preventing angiogenic activation of growth progression. This is the rationale for the use of bevacizumab in ongoing (neo-) adjuvant clinical trials with breast cancer patients.

\section{Targeting DTC by Activation of the Immune System}

An interesting treatment strategy may be the use of therapeutic cancer vaccines $[40,41]$. Cancer vaccines are based on the assumption that the T-cell repertoire of individuals contain cytotoxic T-cell precursors specific for tumor-associated antigens (TAAs, e.g. CEA, MUC-1) or tumor primed memory T-cells and that the patient's immune system can be sensitized to TAAs of the patient's own tumor. Therapeutic vaccines may be particularly effective in patients with (dormant) MRD since the effector/target ratio is more favorable. Currently, a limited number of adjuvant trials are in progress.

\section{Conclusion}

Besides the prognostic information derived from the detection of DTC/CTC, the presence of these cells may also provide a tool for predicting and monitoring the efficacy of systemic therapy. The study with the highest level of evidence for CTC performed to date has been in patients with metastatic disease. However, CTC measurements might also have particular clinical relevance in the context of adjuvant systemic therapy. The molecular characterization of these cells should allow further insights into the biology of metastatic dissemination and therefore help to improve treatment and develop 
new therapeutic approaches. Prospective clinical studies are now ongoing to evaluate whether eradication of CTC in the blood (and also DTC in BM) is correlated with a longer disease-free period and overall survival in the adjuvant setting and if therapy guided by CTC is able to improve outcome of metastatic patients. An additional important goal is the possibility of identifying DTC/CTC-specific targets in order to improve current therapies.

\section{Conflict of Interest}

Volkmar Müller has received research funding by Aventis Pharma and Roche Pharma. Tanja Fehm has received research funding from Novartis and Roche Pharma. Wolfgang Janni has received an unrestricted educational grant from Veridex. Gerhard Gebauer has received research funding by Roche Pharma. Erich Solomayer has declared no potential conflict of interest. Klaus Pantel has received an unrestricted educational grant from Veridex.

\section{References}

$>_{1}$ Weber T, Lacroix J, Weitz J, Amnan K, Magener A, Holting T, Klar E, Herfarth C, von Knebel Doeberitz M: Expression of cytokeratin 20 in thyroid carcinomas and peripheral blood detected by reverse transcription polymerase chain reaction. $\mathrm{Br} \mathrm{J}$ Cancer 2000;82:157-60.

2 Cote RJ, Rosen PP, Lesser ML, Old LJ, Osborne MP: Prediction of early relapse in patients with operable breast cancer by detection of occult bone marrow micrometastases. J Clin Oncol 1991;9:1749-56.

-3 Diel IJ, Solomayer EF, Costa SD, Gollan C, Goerner R, Wallwiener D, Kaufmann M, Bastert $\mathrm{G}$ : Reduction in new metastases in breast cancer with adjuvant clodronate treatment. N Engl J Med 1998;339:357-63.

4 Fields KK, Elfenbein GJ, Trudeau WL, Perkins JB, Janssen WE, Moscinski LC: Clinical significance of bone marrow metastases as detected using the polymerase chain reaction in patients with breast cancer undergoing high-dose chemotherapy and autologous bone marrow transplantation. J Clin Oncol 1996;14:1868-76.

$\checkmark 5$ Gebauer G, Fehm T, Merkle E, Beck EP, Lang N, Jager W: Epithelial cells in bone marrow of breast cancer patients at time of primary surgery: clinical outcome during long-term follow-up. J Clin Oncol 2001;19:3669-74.

6 Braun S, Vogl FD, Naume B, Janni W, Osborne M, Coombes RC, Schlimok G, Diel I, Gerber B, Gebauer G, Pierga JY, Marth C, Oruzio D, Wiedswang G, Solomayer E, Kundt G, Strobl B, Fehm T, Wong GY, Bliss J, Vincent-Salomon A, Pantel K International pooled analysis of prognostic significance of bone marrow micrometastasis in patients with stage I, II, or III breast cancer. N Engl J Med 2005;353:793-802.

7 Janni W, Wiedswang G, Fehm T, Jueckstock J, Borgen E, Rack B, Braun S, Sommer H, Pantel K, Naume B: Persistence of disseminated tumor cells (DTC) in bone marrow (BM) of breast cancer patients predicts increased risk for relapse - results of pooled European data. J Clin Oncol 2006;24:abstr 10083.

$>8$ Zach O, Lutz D: Tumor cell detection in peripheral blood and bone marrow. Curr Opin Oncol 2006; 18:48-56.

9 Müller V, Hayes D, Pantel K: Recent translational research: circulating tumor cells in breast cancer patients. Breast Can Res 2006;8:110.

10 Benoy IH, Elst H, Philips M, Wuyts H, Van Dam P, Scharpe S, Van Marck E, Vermeulen PB, Dirix LY: Real-time RT-PCR detection of disseminated tumour cells in bone marrow has superior prognostic significance in comparison with circulating tumour cells in patients with breast cancer. Br J Cancer 2006;94:672-80.
11 Ntoulia M, Stathopoulou A, Ignatiadis M, Malamos N, Mavroudis D, Georgoulias V, Lianidou ES: Detection of mammaglobin A-mRNA-positive circulating tumor cells in peripheral blood of patients with operable breast cancer with nested RT-PCR. Clin Biochem 2006;39:879-87.

12 Xenidis N, Perraki M, Kafousi M, Apostolaki S, Bolonaki I, Stathopoulou A, Kalbakis K, Androulakis N, Kouroussis C, Pallis T, Christophylakis C, Argyraki K, Lianidou ES, Stathopoulos S, Georgoulias V, Mavroudis D: Predictive and prognostic value of peripheral blood cytokeratin-19 mRNA-positive cells detected by real-time polymerase chain reaction in node-negative breast cancer patients. J Clin Oncol 2006;24:3756-62.

13 Quintela-Fandino M, Lopez JM, Hitt R, Gamarra S, Jimeno A, Ayala R, Hornedo J, Guzman C, Gilsanz F, Cortes-Funes H: Breast cancer-specific mRNA transcripts presence in peripheral blood after adjuvant chemotherapy predicts poor survival among high-risk breast cancer patients treated with high-dose chemotherapy with peripheral blood stem cell support. J Clin Oncol 2006;24:3611-8.

14 Cristofanilli M, Budd GT, Ellis MJ, Stopeck A, Matera J, Miller MC, Reuben JM, Doyle GV, Allard WJ, Terstappen LW, Hayes DF: Circulating tumor cells, disease progression, and survival in metastatic breast cancer. N Engl J Med 2004;351: 781-91.

15 Hayes DF, Cristofanilli M, Budd GT, Ellis MJ, Stopeck A, Miller MC, Matera J, Allard WJ, Doyle GV, Terstappen LW: Circulating tumor cells at each follow-up time point during therapy of metastatic breast cancer patients predict progressionfree and overall survival. Clin Cancer Res 2006; 12:4218-24.

16 Budd GT, Cristofanilli M, Ellis MJ, Stopeck A, Borden E, Miller MC, Matera J, Repollet M, Doyle GV, Terstappen LW, Hayes DF: Circulating tumor cells versus imaging - predicting overall survival in metastatic breast cancer. Clin Cancer Res 2006;12:6403-9.

17 Cristofanilli M, Mendelsohn J: Circulating tumor cells in breast cancer: advanced tools for 'tailored' therapy? Proc Natl Acad Sci USA 2006;103: 17073-4.

18 Müller V, Riethdorf S, Loibl S, Komor M, Houber J, Schrader I, Conrad M, Untch M, von Minckwitz G, Pantel K: Prospective monitoring of circulating tumor cells in breast cancer patients treated with primary systemic therapy - a translational project of the German Breast Group study GeparQuattro. J Clin Oncol 2007;25:abstr 21085.
19 Rack BK, Schindlbeck C, Schneeweiss A, Hilfrich J, Lorenz R, Beckmann MW, Pantel K, Lichtenegger W, Sommer HL, Janni WJ: Prognostic relevance of circulating tumor cells (CTCs) in peripheral blood of breast cancer patients before and after adjuvant chemotherapy: the German SUCCESSTrial. J Clin Oncol 2008;26:abstr 503.

20 Fehm T, Sagalowsky A, Clifford E, Beitsch P, Saboorian H, Euhus D, Meng S, Morrison L, Tucker T, Lane N, Ghadimi BM, Heselmeyer-Haddad K, Ried T, Rao C, Uhr J: Cytogenetic evidence that circulating epithelial cells in patients with carcinoma are malignant. Clin Cancer Res 2002;8:2073-84.

21 Gangnus R, Langer S, Breit E, Pantel K, Speicher MR: Genomic profiling of viable and proliferative micrometastatic cells from early-stage breast cancer patients. Clin Cancer Res 2004;10:3457-64.

22 Woelfle U, Cloos J, Sauter G, Riethdorf L, Janicke F, van Diest P, Brakenhoff R, Pantel K: Molecular signature associated with bone marrow micrometastasis in human breast cancer. Cancer Res 2003;63:5679-84.

-23 Bernards R, Weinberg RA: A progression puzzle. Nature 2002;418:823.

24 Pantel K, Schlimok G, Braun S, Kutter D, Lindemann F, Schaller G, Funke I, Izbicki JR, Riethmuller G: Differential expression of proliferationassociated molecules in individual micrometastatic carcinoma cells. J Natl Cancer Inst 1993;85:1419-24.

25 Müller V, Stahmann N, Riethdorf S, Rau T, Zabel T, Goetz A, Jänicke F, Pantel K: Circulating tumor cells in breast cancer: correlation to bone marrow micrometastases, heterogeneous response to systemic therapy and low proliferative activity. Clin Cancer Res 2005;11:3678-85.

26 Balic M, Lin H, Young L, Hawes D, Giuliano A, McNamara G, Datar RH, Cote RJ: Most early disseminated cancer cells detected in bone marrow of breast cancer patients have a putative breast cancer stem cell phenotype. Clin Cancer Res 2006;12: 5615-21.

27 Alix-Panabières C, Vendrell J-P, Pellé O, Riethdorf S, Müller V, Fabbro M, Pantel K: Detection and characterization of putative metastatic precursor cells in cancer patients. Clin Chem 2007;53:537-39.

-28 Slamon DJ, Godolphin W, Jones LA, Holt JA, Wong SG, Keith DE, Levin WJ, Stuart SG, Udove J, Ullrich A: Studies of the HER-2/neu proto-oncogene in human breast and ovarian cancer. Science 1989;244:707-12.

29 Coussens L, Yang-Feng TL, Liao YC, Chen E, Gray A, McGrath J, Seeburg PH, Libermann TA, Schlessinger J, Francke U, et al.: Tyrosine kinase receptor with extensive homology to EGF receptor shares chromosomal location with neu oncogene. Science 1985;230:1132-9. 
30 Schechter AL, Stern DF, Vaidyanathan L, Decker SJ, Drebin JA, Greene MI, Weinberg RA: The neu oncogene: an erb-B-related gene encoding a 185.000-Mr tumour antigen. Nature 1984;312:513-6.

31 Cameron D, Casey M, Press M, Lindquist D, Pienkowski T, Romieu CG, Chan S, JagielloGruszfeld A, Kaufman B, Crown J, Chan A, Campone M, Viens P, Davidson N, Gorbounova V, Raats JI, Skarlos D, Newstat B, Roychowdhury D, Paoletti P, Oliva C, Rubin S, Stein S, Geyer CE: A phase III randomized comparison of lapatinib plus capecitabine versus capecitabine alone in women with advanced breast cancer that has progressed on trastuzumab: updated efficacy and biomarker analyses. Breast Cancer Res Treat 2008;112:533-43.

32 Meng S, Tripathy D, Shete S, Ashfaq R, Haley B, Perkins S, Beitsch P, Khan A, Euhus D, Osborne C, Frenkel E, Hoover S, Leitch M, Clifford E, Vitetta E, Morrison L, Herlyn D, Terstappen LW, Fleming T, Fehm T, Tucker T, Lane N, Wang J, Uhr J: HER2 gene amplification can be acquired as breast cancer progresses. Proc Natl Acad Sci U S A 2004;101: 9393-8.

\33 Hayes DF, Walker TM, Singh B, Vitetta ES, Uhr JW, Gross S, Rao C, Doyle GV, Terstappen LW: Monitoring expression of HER-2 on circulating epithelial cells in patients with advanced breast cancer. Int J Oncol 2002;21:1111-7.

-34 Ditsch N, Mayer B, Rolle M, Untch M, Schildberg FW, Funke I: Estrogen receptor expression profile of disseminated epithelial tumor cells in bone marrow of breast cancer patients. Recent Results Cancer Res 2003;162:141-7.
35 Reuben JL, Li C, Broglio K, Valero V, Jackson S, Ueno N, Krishnamurthy S, Hortobagyi G, Cristofanilli M: Genomic of circulating tumor cells in metastatic breast cancer. J Clin Oncol 2007;25:abstr 1002.

36 Santini D, Vespasiani Gentilucci U, Vincenzi B, Picardi A, Vasaturo F, La Cesa A, Onori N, Scarpa $\mathrm{S}$, Tonini G: The antineoplastic role of bisphosphonates: from basic research to clinical evidence. Ann Oncol 2003;14:1468-76.

37 Aft R, Watson M, Ylagan L, Chavez-MacGregor M, Trinkaus K, Zhai J, Naughton M, Weilbaecher $\mathrm{K}$ : Effect of zoledronic acid on bone marrow micrometastases in women undergoing neoadjuvant chemotherapy for breast cancer. J Clin Oncol 2008; 26:abstr 1021.

38 Rack B, Janni W, Schoberth A, Heinrigs M, Schindlbeck C, Strobl B, Blankenstein T, Sommer $\mathrm{H}$, Friese $\mathrm{K}$ : Secondary adjuvant therapy with zoledronate in patients with early breast cancer: is there an effect on persisting isolated tumor cells (ITC) in the bone marrow (BM)? Breast Cancer Res Treat 2004;88(suppl 1):abstr 6019.

39 Miller K, Wang M, Gralow J, Dickler M, Cobleigh M, Perez EA, Shenkier T, Cella D, Davidson NE: Paclitaxel plus bevacizumab versus paclitaxel alone for metastatic breast cancer. N Engl J Med 2007;357: 2666-76.

40 Curigliano G, Rescigno M, Goldhirsch A: Immunology and breast cancer: therapeutic cancer vaccines. Breast 2007:16(suppl 2):S20-6.
1 Ko BK, Kawano K, Murray JL, Disis ML, Efferson CL, Kuerer HM, Peoples GE, Ioannides CG: Clinical studies of vaccines targeting breast cancer. Clin Cancer Res 2003;9:3222-34.

42 Solomayer EF, Becker S, Pergola-Becker G, Bachmann R, Kramer B, Vogel U, Neubauer H, Wallwiener D, Huober J, Fehm TN: Comparison of HER2 status between primary tumor and disseminated tumor cells in primary breast cancer patients. Breast Cancer Res Treat 2006;98:179-84.

43 Becker S, Becker-Pergola G, Wallwiener D, Solomayer EF, Fehm T: Detection of cytokeratin-positive cells in the bone marrow of breast cancer patients undergoing adjuvant therapy. Breast Cancer Res Treat 2006;97:91-6.

44 Braun S, Schlimok G, Heumos I, Schaller G, Riethdorf L, Riethmuller G, Pantel K: ErbB2 overexpression on occult metastatic cells in bone marrow predicts poor clinical outcome of stage I-III breast cancer patients. Cancer Res 2001;61:1890-95.

45 Vincent-Salomon A, Couturier J, Nos C, Sastre-Garau X, Pouillart P, Magdelénat $\mathrm{H}$, Thiery J, Sigal-Zafrani B, Pierga J: HER2 gene status assessment in micrometastatic cells in bone marrow (BM) of breast cancer patients by fluorescence in situ hybridization. J Clin Oncol 2004;22:9520. 